\title{
Peningkatan Life Skills Warga Belajar melalui Kursus Komputer di PKBM Cipta Cendekia Kota Tangerang
}

\author{
Bela Trisnawati ${ }^{凶}$, S. Sudadio, Ahmad Fauzi \\ Pendidikan Luar Sekolah Universitas Tirtayasa Banten
}

DOI: $10.15294 /$ pls.v1i2.19418

\section{Info Artikel}

Sejarah Artikel:

Diterima Oktober 2017

Disetujui November 2017

Dipublikasikan Desember 2017

Keywords: effort; life skills; computer courses; PKBM

\begin{abstract}
Abstrak
Tujuan penelitian ini mengetahui upaya, hasil, faktor pendukung dan penghambat peningkatan life skills warga belajar melalui kursus komputer. Pendekatan penelitian yang digunakan adalah deskriptif kualitatif dengan data diperoleh dari hasil wawancara, observasi, dokumentasi, tes tertulis dan tes praktik. Sumber data penelitian diperoleh dari tutor, warga belajar, dan pengelola. Data dianalisis menggunakan triangulasi sumber, metode, dan teori. Hasil penelitian menunjukkan bahwa upaya tutor dalam meningkatkan keterampilan komputer warga belajar paket $\mathrm{B}$ dan $\mathrm{C}$ berjalan dengan baik dan berhasil. Peserta kursus mendapatkan hasil dengan memiliki kemampuan kognitif, afektif serta skills yang membantu peserta kursus mudah mendapatkan pekerjaan dan memiliki usaha. Faktor pendukung adalah tingginya tingkat kemauan warga belajar, sarana dan prasarana yang memadai, media dan metode pembelajaran yang cukup baik, serta bantuan dana dari APBD yang cukup membantu. Faktor penghambatnya adalah kurangnya perekrutan peserta, komputer yang rusak dan jumlahnya sedikit dibandingkan dengan jumlah peserta kursus, terbatasnya bantuan dana alokasi APBD, dan kurangnya jumlah tutor.
\end{abstract}

\section{Abstract}

The purpose of this study is to know the efforts, outcomes, supporting factors and inhibiting the increase of citizen life skills through computer courses. The research approach used is descriptive qualitative with data obtained from interviews, observation, documentation, written test and practice test. Sources of research data obtained from tutors, study residents, and managers. Data were analyzed using source triangulation, method, and theory. The results showed that the tutor's efforts in improving the computer skills of citizens learning the $B$ and $C$ package run well and successfully. Course participants get results with cognitive, affective and skills skills that help course participants find work and have a business. Supporting factors are the high level of willingness of studying citizens, adequate facilities and infrastructure, media and learning methods are quite good, as well as aid funds from the APBD is quite helpful. Inhibiting factors are lack of recruiting, damaged computers and fewer number of participants, limited allocation of $A P B D$ funds, and lack of tutors.

Alamat korespondensi:

E-mail: bela.trisnawati@yahoo.co.id 


\section{PENDAHULUAN}

Pendidikan memegang peran penting dalam pembangunan nasional yang mana melalui pendidikan yang baik, akan terlahir manusia Indonesia yang mampu bersaing di era globalisasi dengan tingginya persaingan dalam semua aspek. Pada zaman era globalisasi yang tinggi ini, maka setiap orang harus dapat memiliki kecakapan hidup (life skills) yang melekat pada dirinya. Karena kecakapan hidup merupakan suatu upaya pendidikan untuk meningkatkan kapasitas dan kapabilitas setiap warga negara. Kecakapan hidup terbagi menjadi empat jenis yaitu kecakapan personal, akademik, sosial dan vokasional.

Herlinda et al. (2017) mengungkap bahwa hasil pelatihan dapat meningkatkan kecakapan hidup yang mencakup kecakapan personal, sosial, akademik, dan vokasional. Adapun pengertian kecakapan hidup menurut Depdiknas (2002) adalah kecakapan yang dimiliki seseorang untuk berani menghadapi problema hidup dan kehidupan dengan wajar tanpa merasa tertekan, kemudian secara proaktif dan kreatif mencari serta menemukan solusi sehingga akhirnya mampu mengatasinya. Demikian menurut UNESCO dalam Anwar (2006) menyampaikan program life skills berpegang pada empat pilar pembelajaran, yaitu belajar memperoleh pengetahuan (learning to know), belajar untuk bisa berbuat/bekerja (learning to do), belajar menjadi orang yang berguna (learning to be), dan belajar untuk dapat hidup bersama (learning to live together).

Pelaksanaan pembangunan menuntut adanya tenaga kerja yang memiliki keterampilan, kecakapan dalam berbagai kegiatan. Sehingga target yang telah ditetapkan dapat tercapai dengan baik. Dalam hal ini perlu adanya pemberdayaan, pelatihan serta program-program kursus yang akan membantu menghadapi permasalahan pada diri manusia yakni memperkuat dan meningkatkan kemampuan dan keterampilan pada diri manusia itu sendiri. Hal ini dijelaskan dalam Undang-undang No. 20 Tahun 2003 tentang Sistem Pendidikan Nasional, memberikan dasar hukum untuk membangun pendidikan nasional dengan menerapkan prinsip demokrasi, otonomi, keadilan dan menjunjung tinggi hak asasi manusia. Penerapan semua ketentuan dalam Undang-undang ini diharapkan untuk mendukung segala upaya memecahkan masalah pendidikan yang pada gilirannya akan dapat memberikan sumbangan yang signifikan terhadap masalah-masalah makro bangsa Indonesia khususnya terhadap masalah pengangguran.

Pendidikan nonformal sebagai salah satu jalur dalam sistem pendidikan nasional yang memiliki peranan penting dalam memberikan layanan pendidikan bagi masyarakat. Karena masyarakat tentunya sangat membutuhkan dan merupakan upaya pemberdayaan masyarakat untuk meningkatkan kemampuan masyarakat agar dapat berkembang sesuai dengan keterampilan yang akan ia miliki. Menurut Sudjana (2004:44) pendidikan luar sekolah adalah,

setiap usaha pelayanan pendidikan luar sistem sekolah, berlangsung seumur hidup, dijalankan dengan sengaja, teratur dan berencana yang bertujuan mengaktualisasi potensi manusia (sikap, tindak dan karya) sehingga dapat terwujud manusia seutuhnya yang gemar belajar dan mampu meningkatkan taraf hidupnya.

Tingkat pengangguran sebagian besar dilatarbelakangi oleh tingkat pendidikan yang hanya berpendidikan SD dan SMP. Hal ini terjadi pada masyarakat di PKBM Cipta Cendekia Kecamatan Cipondoh Kota Tangerang. Terdapat beberapa faktor yang menyebabkan terjadinya pengangguran, pertama jumlah pencari kerja lebih besar dari pada jumlah kesempatan kerja yang tersedia. Kedua, kesenjangan antara kualitas pencari kerja dengan kualifikasi yang dibutuhkan oleh pasar kerja. Faktor tersebut merupakan faktor dominan yang menyebabkan pengangguran. Maka dari itu, untuk mengurangi masalah tersebut perlu adanya penyelenggaraan pendidikan yang sesuai dengan perkembangan jaman di Indonesia sebagai negara berkembang. Kemajuan pendidikan melalui jalur formal maupun nonformal 
diharapkan akan meningkatkan kemampuan dan keterampilan seseorang.

PKBM Cipta Cendekia telah terlaksana program kursus komputer untuk meningkatkan keterampilan life skills warga belajarnya. Hal yang menjadi alasan PKBM Cipta Cendekia melaksanakan program kursus komputer tersebut yaitu karena tutor dalam melakukan pembelajaran di kelas kesetaraan paket $\mathrm{B}$ dan kesetaraan paket $\mathrm{C}$ beradaptasi dengan warga belajar, melakukan pendekatan sehingga dapat melihat dan mengidentifikasikan sebelumnya. Bahwasanya warga belajar di PKBM Cipta Cendekia drop out sekolah pada jenjang SD dan SMP, sehingga warga belajar tidak mempunyai keterampilan computer, oleh karenanya menjadikan warga belajar buta dengan teknologi komputer. Bahwa pada zaman sekarang ini teknologi komputerisasi di dunia semakin cangging. Jika setiap orang tidak memiliki keterampilan komputer maka orang tersebut bisa ketinggalan zaman. Maka dari itu pengelola serta tutor bekerjasama untuk menjalankan dan melaksanakan kursus komputer, agar dapat meningkatkan dan memberikan bekal keterampilan komputer pada warga belajarnya. Karena di zaman sekarang bukan hanya ilmu pengetahuan saja yang jadi modal dasar untuk mendapatkan pekerjaan, sekarang keterampilan atau life skills yang dimiliki akan sangat berguna untuk mendapatkan pekerjaan atau membuka usaha secara mandiri.

Program kursus komputer di PKBM Cipta Cendekia, tutor sangat berperan penting dalam pelaksanaan kegiatan. Karena tutorlah yang melakukan pendekatan sehingga dapat melihat dan mengidentifikasikan sebelumnya bahwasanya warga belajar membutuhkan bekal keterampilan komputer pada dirinya dan tutor juga memotivasi warga belajar untuk mengikuti kursus komputer tersebut. Tutorlah yang mengajarkan teori komputer serta praktik menggunakan komputer. Peran pengelola hanya memfasilitasi dan mendukung terlaksananya program kursus komputer.

Kursus sebagai salah satu bentuk penyelenggaraan pendidikan pada jalur pendidikan nonformal, mempunyai kaitan yang sangat erat dengan jalur pendidikan formal. Selain memberikan kesempatan bagi peserta didik yang ingin mengembangkan keterampilan jenis pendidikan tertentu, yang telah ada di jalur pendidikan formal juga memberikan kesempatan bagi masyarakat yang ingin mengembangkan pendidikan keterampilannya yang tidak dapat ditempuh dan tidak terpenuhi pada jalur pendidikan formal.

Menurut Artasasmita (1985:10) kursus adalah,

Suatu kegiatan pendidikan yang dilakukan sengaja, terorganisir dan sistematik untuk memberikan satu mata pelajaran atau rangkaian pelajaran tertentu pada orang dewasa atau remaja tertentu dalam waktu yang relatif singkat, agar mereka memperoleh pengetahuan, keterampilan dan sikap yang dapat dimanfaatkan untuk mengembangkan dirinya dan masyarakatnya.

Lembaga pendidikan kursus merupakan lembaga pendidikan nonformal yang dapat menyelenggarakan kursus keterampilan komputer dalam upaya meningkatkan keterampilan warga masyarakat. Program yang dilaksanakan pada kursus komputer yaitu: program komputer dasar (Microsoft Windows, Mengetik 10 Jari), paket aplikasi perkantoran Microsoft Office (Ms. Word, Ms. Excel, Ms. Power Point), teknisi komputer (Perakitan dan Troubleshooting PC), pemrograman Database, Microsoft Access, Dasain Grafis (Macromedia Freehand, CorelDraw, Xara X, Adobe Photoshop). Kegiatan ini dilaksanakan secara berkelanjutan dan telah melahirkan lulusan yang berkualitas dan siap menghadapi tantangan global. Kursus komputer memberikan kesempatan bagi masyarakat yang ingin mengembangkan pendidikan keterampilannya dalam mengoperasikan komputer yang tidak dapat ditempuh dan tidak terpenuhi pada jalur pendidikan formal. Biasanya dalam kursus komputer program Microsoft Office dan Desain Grafis yang sering diajarkan sebagai materi ajar pelaksanaan kursus komputer, karena Microsoft Office dan Desain Grafis sering digunakan sebagai pekerjaan diperkantoran. 


\section{METODE}

Penelitian ini menggunakan pendekatan kualitatif. Artinya data yang dikumpulkan bukan berupa angka-angka, melainkan data tersebut berasal dari naskah wawancara, catatan lapangan, dokumen pribadi, catatan memo, dan dokumen resmi lainnya. Oleh karenanya tujuan penelitian yang menggambarkan realita empirik di balik fenomena secara mendalam, rinci dan tuntas dapat tercapai. Penelitian dilakukan di PKBM Cipta Cendekia yang merupakan salah satu PKBM di Kecamatan Cipondoh Kota Tangerang, Provinsi Banten.

Data penelitian diperoleh dari subjek penelitian sebagai sumber data yang terdiri dari tutor kursus komputer, warga belajar, dan pengelola. Yang mengikuti kursus komputer di PKBM Cipta Cedekia adalah warga belajar dari paket $\mathrm{B}$ dan paket $\mathrm{C}$ yang mempunyai kemauan yang tinggi untuk meningkatkan keterampilan komputernya.

Pengumpulan data dilakukan dengan tiga tahap; tahap orientasi, eksplorasi, dan member chek. Teknik pengumpulan data menggunakan wawancara, observasi, studi dokumentasi, dan angket dalam bentuk instrumen tes mencakup tes tulis, dan tes praktik. Adapun teknik analisis data mencakup reduksi data, data display, dan kesimpulan/verifikasi.

\section{HASIL DAN PEMBAHASAN}

\section{Upaya Peningkatan Life skills}

Learning to Know (belajar untuk memperoleh pengetahuan)

Learning to know ini adalah tahap awal dari program kursus computer. Karena learning to know merupakan kemampuan kognitif (pengetahuan) yang akan didapatkan oleh peserta kursus komputer setelah mengikuti kursus komputer. Pengetahuan ini berupa teori komputer akan didapatkan oleh peserta kursus komputer yaitu Microsoft Word, Microsoft Excel, dan Microsoft Power Point. Berdasarkan hasil wawancara dengan tutor kursus komputer, bahwa tutor menyusun teori-teori komputer yang akan diajarkan kepada para peserta kursus secara tersusun. yang pertama tutor mengajarkan Microsoft Word, yang kedua Microsoft Excel dan yang terakhir Microsoft Power Point. Dengan tersusunnya teori yang akan diajarkan tutor, dapat memudahkan peserta kursus untuk mengingat dan memahaminya, sehingga akan meningkatkan kemampuan kognitif bagi peserta kursus. Karena ketiga teori komputer tersebut yang akan diajarkan oleh tutor dalam proses pembelajaran kursus komputer. Karena pengetahuan yang akan dimiliki akan penting untuk dapat mempraktikkannya.

Learning to Do (belajar untuk dapat berbuat atau bekerja)

Maksud dari learning to do dalam pembelajaran kursus komputer di PKBM Cipta Cendekia adalah teori belajar yang dipilih hendaknya mampu memberikan suatu pekerjaan alternatif kepada peserta kursus. Oleh karenanya pembelajaran yang sudah diajarkan akan berbuah positif untuk dapat berbuat atau bekerja. Yang diharapkan tutor/intruktur dari proses pembelajaran kursus komputer ini adalah peserta kursus dapat mengoperasikan komputer serta keluarannya pun dapat bekerja dengan menggunakan keterampilan komputer yang telah dipelajarinya selama mengikuti kursus, sehingga peserta tidak sia-sia dalam belajar komputer. Hal ini terungkap dari hasil wawancara dengan tutor kursus komputer dan beberapa warga belajar peserta kursus komputer. Bahwa tutor disini dalam proses pembelajaran kursus komputer menggunakan metode pembelajaran yaitu metode ceramah dan metode demonstrasi. Jadi dalam proses belajar mengajar komputer, tutor menjelaskan teori-teori komputer misalnya Microsoft Word dengan ceramah di depan kelas, setelah dijelaskan lalu tutor meminta peserta kursus untuk mempraktikkan teori yang sudah dijelaskan dengan menggunakan komputer atau laptop yang sudah disediakan. Jadi dalam tahap ini, peserta kursus akan dapat mengoperasikan komputer setelah ia memiliki pengetahuan yang berupa teori komputer yaitu Microsoft Word, Microsoft Excel, dan Microsoft Power Point. Hasil yang didapatkan peserta kursus dapat bekerja dengan menggunakan keterampilan komputer yang telah ia kuasai. 
Learning to be (belajar untuk menjadi orang yang berguna)

Pada dasarnya yang diharapkan dari belajar yaitu untuk menjadi orang yang berguna, dengan belajar kita mendapatkan wawasan dan pengetahuan yang luas. Hasil penelitian program kursus komputer yang dilaksanakan di PKBM Cipta Cendekia bertujuan meningkatkan keterampilan life skills warga belajar paket B dan paket C khususnya pada bidang komputer. Karena jika warga belajar paket $\mathrm{B}$ dan paket $\mathrm{C}$ tidak mengikuti keterampilan life skills, maka setelah lulus nanti warga belajar hanya mendapatkan kemampuan kognitif dan kemampuan afektif saja, yang berupa ijazah dari hasil kelulusan.

Zaman sekarang mencari pekerjaan sangat sulit, bukan hanya pengetahuan saja yang dibutuhkan dalam bekerja, tetapi keterampilan life skills pun sangat dibutuhkan. Learning to be ini merupakan kecakapan personal yang dimiliki oleh seseorang untuk memiliki kesadaran akan potensi dirinya. Kesadaran akan potensi diri adalah kesadaran yang dimiliki seseorang atas kemampuan dirinya. Dengan kesadaran atas kemampuan diri itu seseorang akan tahu kelebihan dan kekurangannya, kekuatan dan kelemahannya. Dengan kesadaran potensi diri, seseorang akan dapat menempuh kehidupan dengan wajar tanpa merasa tertekan dan mampu memecahkan masalah hidup serta menjadi orang yang berguna bagi dirinya sendiri maupun orang lain. Dengan mengikuti kursus komputer, maka setelah lulus nanti warga belajar pun mendapatkan keterampilan skills di bidang komputer, yang akan berguna untuk mendapatkan pekerjaan. Selain memudahkan mendapatkan pekerjaan, warga belajar dapat membuka peluang usaha mandiri seperti bisnis, usaha online, warung internet (Warnet) dan sejenis lainnya.

Learning to live together (belajar untuk dapat hidup bersama dengan orang lain)

Tahap ini pembelajaran tidak hanya cukup diberikan dalam bentuk pengetahuan dan keterampilan saja, tetapi pembelajaran pun diarahkan untuk dapat hidup bersama dengan orang lain. Berdasarkan hasil wawancara dengan tutor, bahwa tutor tidak hanya mengajarkan ketiga teori komputer, tetapi tutor juga memberikan motivasi dan arahan yang benar dan baik kepada warga belajarnya untuk hidup bersama dengan orang lain. Karena manusia tidak akan bisa hidup sendiri tanpa adanya orang lainnya di sekitarnya.

Proses pembelajaran kursus komputer di kelas, tutor memberikan motivasi agar tidak pernah malu untuk bertanya. Karena dalam dunia perkerjaan dan usaha persaingan yang ketat dan bagi orang yang memiliki sikap cuek dan malu akan tertinggal. Tutor memberikan motivasi kepada peserta kursus untuk saling berbaur, menyapa dan membantu, hal tersebut untuk melatih para peserta untuk dapat beradaptasi serta bekerjasama dengan orang lain. Karena dalam dunia kerja dan usaha harus saling bekerjasama dan mampu beradaptasi dengan orang lain.

Anwar (2006) selain menyampaikan empat pilar pembelajaran berupa learning to know, learning to do, learning to be, dan learning to live together, juga menegaskan ciri-ciri pembelajaran kecakapan hidup yaitu,

a) Terjadi proses identifikasi kebutuhan belajar.

b) Terjadinya proses penyadaran untuk belajar bersama.

c) Terjadi keselarasan kegiatan belajar untuk mengembangkan diri, belajar, usaha mandiri, dan usaha bersama.

d) Terjadi proses pemberian pengalaman dalam melakukan pekerjaan dengan benar, menghasilkan produk bermutu.

e) Terjadi proses penguasaan kecakapan personal, sosial, vokasional, akademik, manajerial, dan kewirausahaan.

f) Terjadi proses interaksi saling belajar dari para ahli.

g) Terjadi proses penilaian kompetensi.

h) Terjadinya pendampingan teknik untuk bekerja atau membentuk usaha mandiri.

(Anwar, 2006:21).

Program pembelajaran akan memberikan hasil pembelajaran yang berupa pengetahuan (learning to know) untuk dapat mengimplementasikannya. Bahwa tutor mengatakan sebagai tutor kursus 
harus mampu menempatkan dirinya sebagai fasilitator, disamping itu juga tutor dapat berperan ganda sebagai kawan berdialog bagi peserta kursus dalam rangka mengembangkan penguasaan pengetahuan peserta kursus.

Teori komputer yang dipilih hendaknya mampu memberikan suatu pekerjaan alternatif kepada peserta kursus (learning to do). Dalam proses belajar komputer tidak sekedar untuk menambah pengetahuan peserta, tetapi untuk terampil dalam menguasai ketiga teori komputer yang sudah diajarkan, sehingga menghasilkan sesuatu yang bermakna bagi kehidupannya. Keterampilan merupakan sarana untuk menopang kehidupan seseorang bahkan keterampilan lebih domain dari pada penguasaan pengetahuan semata. Penguasaan pengetahuan dan keterampilan merupakan bagian dari proses menjadi orang yang berguna (learning to be), dengan memiliki keterampilan komputer tersebut maka peserta mampu mendapatkan pekerjaan dan usaha dengan bekal keterampilan komputernya.

Pembelajaran tidak cukup hanya diberikan dalam bentuk keterampilan untuk dirinya sendiri, tetapi juga keterampilan untuk hidup bertetangga, bermasyarakat, berbangsa, dan hidup dalam pergaulan antar bangsa-bangsa dengan semangat kesamaan dan kesejajaran (learning to live together). Dengan kemampuan yang akan dimiliki peserta kursus sebagai hasil proses belajar, dapat dijadikan sebagai bekal untuk mampu berperan dalam lingkungan dimana individu tersebut berada, dan sekaligus mampu menempatkan diri sesuai dengan perannya. Pemahaman tentang peran diri dan orang lain dalam kelompok belajar merupakan bekal dalam bersosialisasi di masyarakat.

\section{Hasil Peningkatan Life Skills}

Hasil wawancara yang dilakukan kepada tutor kursus komputer mengenai hasil apa saja yang didapatkan selama mengikuti kursus computer, tutor menjelaskan peserta kursus mendapatkan banyak sekali ilmu selama kegiatan pembelajaran berlangsung mencakup kemampuan kognitif, afektif, dan psikomotorik (skill). Terkait kemampuan kognitif, sesuai dengan tujuan peserta kursus mengikuti kursus komputer untuk mendapatkan pengetahuan yang berupa teori komputer yaitu Microsoft Word, Microsoft Excel, dan Microsoft Power Point. Memahami teori tersebut untuk dapat mempraktikkannya dari teori yang telah didapatkan. Pengetahuan mereka bertambah seiring berjalannya kegiatan kursus yang diikutinya.

Berdasarkan hasil tes tertulis yang disertai dengan wawancara kepada tutor kursus komputer, diperoleh data sebagaimana tabel 1 . Kemampuan kognitif berupa nilai yang didapatkan dari tes tertulis dilakukan dengan memberikan format pertanyaan berupa materimateri yang telah disampaikan lalu dijawab oleh peserta kursus komputer.

Kemampuan afektif peserta kursus dilihat dari perubahan pada dirinya, yang dibuktikan dengan peserta dapat menyelesaikan tugas-tugas komputer yang diberikan. Dalam praktiknya, peserta mampu mengaplikasikan dan mempraktikkan materi pembelajaran sesuai dengan apa yang telah diajarkan. Dalam hal tersebut menunjukkan kompetensi peserta bertambah meningkat sebelum mengikuti kursus komputer.

Program kursus komputer di PKBM Cipta Cendekia memberikan bekal pengetahuan dan keterampilan komputer yang terbagi menjadi tiga teori pembelajaran. Teori pembelajaran pertama yang diajarkan oleh tutor adalah Microsoft Word. Setelah peserta dapat memahami serta mempraktikkannya, lalu dilanjutkan dengan pembelajaran yang kedua yaitu Microsoft Excel, dan yang terakhir tutor mengajarkan Microsoft Power Point. Kursus komputer di PKBM Cipta Cendekia hanya mengajarkan peserta kursus Microsoft Office saja.

Hamalik (2003:155), "hasil belajar adalah terjadinya perubahan tingkah laku pada diri seseorang yang dapat diamati dan diukur bentuk pengetahuan, sikap dan keterampilan". Perubahan tersebut dapat diartikan sebagai terjadinya peningkatan dan pengembangan yang tidak tahu menjadi tahu. Sudjana (2003) juga mengemukakan bahwa hasil belajar adalah perubahan tingkah laku yang mencakup bidang 
kognitif, afektif, dan psikomotorik yang dimiliki oleh siswa setelah menerima pengalaman belajar. Demikian yang ditegaskan Hidayat (2017), bahwa hasil pelatihan mengindikasi perubahan atau kemampuan warga belajar dari aspek pengetahuan, dan keterampilan serta sikap pengembangan usaha mandiri.

Teori pembelajaran pertama yaitu Microsoft Word (Ms. Word), materi yang diajarkan tutor meliputi: (1) Pengenalan tentang software, hardware dan brainware pada komputer beserta fungsi dan kegunaannya. (2) Mempelajari cara membuka dan menutup Ms. Word. (3) Mempelajari cara membuka, menyimpan, dan membuat dokumen baru. (4) Mempelajari menu (icon) dan fungsinya yang ada pada Ms. Word seperti Home, Insert, Page Layout, References, Mailings, Review, View. (5) Mempelajari beberapa tombol pintasan pada Ms. Office, misalnya "CTRL C" (untuk mengkopi), "CTRL X" (untuk memindahkan), "CTRL V" (untuk Paste) dan lainnya. (6) Mempelajari cara membuat bagan, tabel, wordart pada Ms. Word. (7) Mempelajari cara penulisan Ms. Word secara benar.

Teori pembelajaran kedua yaitu Microsoft Excel, materi yang diajarkan tutor meliputi: (1) Mempelajari menu (icon) dan fungsinya yang ada pada Ms. Excel. (2) Memepalajari beberapa rumus statistik yang sering digunakan. (3) Mempelajari bagaimana cara menggunakan dan menghitung rumus statistika, seperti: average, min, max, sum, count dan lainnya. Sedangkan pada teori pembelajaran ketiga yaitu Microsoft Power Point, materi yang diajarkan tutor meliputi: (1) Mempelajari menu (icon) dan fungsinya yang ada pada Ms. Power Point. (2) Mempelajari cara membuat power point yang baik, dengan mengganti tampilan desain, background, layout, sesuai dengan topik yang akan dibahas. (3) Mempelajari Custum Animation/Effect secara sederhana untuk menambah tampilan slide agar menarik. (4) Mempelajari Design Templates untuk menambah tampilan slide agar menarik. (5) Mempelajari cara membuka, menyimpan dan menutup Ms. Power Point.
Hasil observasi yang didapatkan, bahwa kursus komputer hanya mengajarkan peserta kursus Microsoft Word, Microsoft Excel, dan Microsoft Power Point secara sederhana yaitu mempelajari yang sering digunakan saja, yang sukar tidak dipelajari terkecuali atas permintaan peserta. Berdasarkan hasil wawancara dengan tutor kursus komputer, bahwa untuk mendapatkan dan mengetahui hasil kursus yang berupa keterampilan (skills) komputer peserta kursus didapatkan dari instrumen pengumpulan data yang berupa tes praktik. Tes yang dilakukan melalui praktik dilakukan oleh peserta kursus sehingga dapat diketahui sejauh mana peserta menguasai materi-materi yang telah disampaikan dan sejauh mana keterampilan komputer yang telah dikuasai. Skills yang didapat dari hasil kursus komputer juga berupa nilai yang didapatkan dari tes praktik. Berikut ini adalah hasil tes praktik peserta kursus komputer tahun 2016-2017 sebagai pada tabel 2.

Hasil kursus komputer didapatkan dari instrumen tes yaitu tes tertulis dan tes praktik. Hasilnya yang diperoleh peserta kursus menunjukkan sudah dapat memahami, mendapatkan pengetahuan baru, dan mempraktikkannya kembali apa yang sudah mereka dapatkan dari hasil kursus. Setelah mengikuti kursus komputer di PKBM Cipta Cendekia peserta mendapatkan pengetahuan, pemahaman, penerapan, dan nilai tentang ketiga teori komputer yang di antarnya Ms. Word, Ms. Excel, dan Ms. Power Point. Bukan hanya pengetahuan yang bertambah, namun keterampilan dan kesiapan untuk bekerja dan usaha juga bertambah. Peserta kursus juga mengalami perubahan pada dirinya yang tadinya tidak dapat menguasai komputer dan sekarang menjadi bias menguasai penggunaan komputer. Hasil kursus komputer berdaya guna bagi peserta kursus untuk diaplikasikan dalam kehidupannya. Setelah semua aspek kognitif, afektif, dan skills telah dimiliki tentu akan merubah perspektif dalam kehidupannya, seperti rencana-rencana yang akan dijalankan setelah mengikuti kursus. 
Tabel 1. Nilai Kognitif Peserta Kursus Tahun 2016-2017

\begin{tabular}{|c|c|c|c|c|c|c|}
\hline \multirow{2}{*}{ No } & \multirow{2}{*}{ Nama Peserta } & \multicolumn{3}{|c|}{ Nilai Kognitif Ujian Tertulis } & \multirow{2}{*}{ Rata-Rata Nilai } & \multirow{2}{*}{ Nilai } \\
\hline & & Ms. Word & Ms. Excel & Ms. PPT & & \\
\hline 1. & Sulastri & 80 & 80 & 80 & 80 & $\mathrm{~A}$ \\
\hline 2. & Melia Nur Safitri & 95 & 85 & 90 & 90 & A \\
\hline 3. & Windiyawati & 85 & 75 & 80 & 80 & A \\
\hline 4. & Ayu Nurmia & 80 & 75 & 85 & 80 & A \\
\hline 5. & Rokami & 90 & 90 & 90 & 90 & A \\
\hline 6. & Dwi Median Tika & 95 & 85 & 90 & 90 & A \\
\hline 7. & Eka Pernama Sari & 85 & 85 & 85 & 85 & A \\
\hline 8. & Casem Susanti & 90 & 90 & 90 & 90 & A \\
\hline 9. & Dailah & 80 & 80 & 80 & 80 & A \\
\hline 10. & Tursiyah & 85 & 75 & 80 & 80 & $\mathrm{~A}$ \\
\hline 11. & Novi Yanah & 90 & 80 & 85 & 85 & A \\
\hline 12. & Lella Damayanti & 80 & 75 & 85 & 80 & $\mathrm{~A}$ \\
\hline 13. & Sania Restu Firdaus & 90 & 90 & 90 & 90 & $\mathrm{~A}$ \\
\hline
\end{tabular}

Sumber: Data Primer 2017

Tabel 2. Nilai Skills Peserta Kursus Tahun 2016-2017

\begin{tabular}{|c|c|c|c|c|c|c|}
\hline \multirow{2}{*}{ No } & \multirow{2}{*}{ Nama Peserta } & \multicolumn{3}{|c|}{ Nilai Skills Ujian Tertulis } & \multirow{2}{*}{ Rata-Rata Nilai } & \multirow{2}{*}{ Nila } \\
\hline & & Ms. Word & Ms. Excel & Ms. PPT & & \\
\hline 1. & Sulastri & 85 & 75 & 80 & 80 & A \\
\hline 2. & Melia Nur Safitri & 80 & 80 & 80 & 80 & A \\
\hline 3. & Windiyawati & 80 & 70 & 75 & 75 & $\mathrm{~B}$ \\
\hline 4. & Ayu Nurmia & 80 & 80 & 80 & 80 & A \\
\hline 5. & Rokami & 85 & 75 & 80 & 80 & A \\
\hline 6. & Dwi Median Tika & 90 & 75 & 75 & 80 & A \\
\hline 7. & Eka Pernama Sari & 85 & 80 & 75 & 80 & A \\
\hline 8. & Casem Susanti & 85 & 75 & 80 & 80 & A \\
\hline 9. & Dailah & 80 & 75 & 70 & 75 & B \\
\hline 10. & Tursiyah & 85 & 70 & 70 & 75 & B \\
\hline 11. & Novi Yanah & 90 & 80 & 85 & 85 & A \\
\hline 12. & Lella Damayanti & 80 & 70 & 75 & 75 & $\mathrm{~B}$ \\
\hline 13. & Sania Restu Firdaus & 90 & 85 & 80 & 85 & A \\
\hline
\end{tabular}
Sumber: Data Primer 2017

\section{Faktor Pendukung dan Penghambat}

Berdasarkan hasil penelitian, terdapat beberapa faktor pendukung dalam pelaksanaan program kursus komputer di PKBM Cipta Cendekia yang mencakup hal mengenai peserta kursus, sarana prasarana, biaya, dan keberadaan tutor. Faktor pendukung yang bersumber dari peserta kursus yakni tingginya tingkat kemauan untuk meningkatkan keterampilan computer mereka. Kehadiran serta sikap peserta pun menjadi faktor pendukung dalam meningkatkan keterampilan komputer pada dirinya, karena jika para peserta kursus selalu hadir pada jadwal kursus yang telah ditetapkan dan peserta kursus aktif dalam pembelajaran di kelas, maka peserta pun akan cepat mampu menerima semua pembelajaran yang telah diajarkan sehingga tidak tertinggal.

Sarana fisik seperti gedung dan prasarana seperti jalan menuju ke PKBM Cipta Cendekia sangatlah strategis. Karena PKBM Cipta Cendekia terletak di pinggir jalan, dan media pembelajaran dengan menggunakan modul serta komputer dan laptop yang sangat menunjang. Dalam pelaksanaan program kursus komputer di PKBM Cipta Cendekia mendapatkan dana bantuan dari APBD. Bantuan tersebut dipakai untuk transpot tutor, iuran peserta kursus, dan sarana belajar seperti komputer, laptop dan modul belajar. Demikian juga tutor kursus komputer sangat berkompetensi baik dan mahir dalam bidang komputer khususnya pada Microsoft Office.

Hasil penelitian didapatkan beberapa faktor penghambat dalam terlaksananya program kursus komputer di PKBM Cipta Cendekia yang juga mencakup hal mengenai peserta kursus, sarana prasarana, biaya, dan keberadaan tutor. Dari peserta kursus, masih banyaknya warga belajar paket $\mathrm{B}$ dan paket $\mathrm{C}$ yang tidak ingin 
meningkatkan keterampilan komputer pada dirinya. Hal ini meskipun sebelum terlaksananya kursus komputer di PKBM Cipta Cedekia tutor dan pengelola sudah memberikan motivasi kepada warga belajar untuk mengikuti kursus komputer tersebut. Demikian juga tidak adanya peserta kursus dari luar atau yang bukan dari warga belajar di PKBM Cipta Cendekia, karena yang menjadi peserta program kursus diambilkan dari peserta kesetaraan paket $B$ dan paket $C$.

Fasilitas komputer sudah cukup baik, tetapi yang menjadi hambatan adalah jumlah komputer lebih sedikit dibandingkan dengan peserta kursus. Jumlah komputer terdapat 4 unit dan jumlah laptop terdapat 4 unit, sedangkan peserta kursus ada 10 orang. Jadi satu unit komputer dipakai oleh dua orang peserta kursus, maka proses pembelajaran dalam praktik pun kurang nyaman dan tidak kondusif karena saling bergantian untuk memakai komputer atau laptop tersebut. Fasilitasi kursus komputer mendapatkan bantuan dana dari APBD, tetapi para peserta kursus masih diwajibkan untuk membayar sebagian dana sebesar Rp 200.000 untuk proses belajar mengajar. Iuran dana tersebut hanya sekali saja sampai para peserta lulus mengikuti kursus computer.

Sebelum mendapatkan bantuan dana dari APBD, para peserta kursus komputer dikenakan biaya perbulan $\mathrm{Rp}$ 100.000. Dari hal itu warga belajar masih banyak yang tidak mau mengikuti kursus komputer, karena masih membayar iuran yang diwajibkan. Hal ini membuat kurang tertariknya calon peserta mengikuti program kursus. Di samping itu, tutor kursus komputer kurang sosialisasi ke luar PKBM, sehingga masyarakat di sekitar lingkungan hanya mengetahuai program yang dilaksanakan PKBM Cipta Cendekia hanya program kesetaraan paket $A$, paket $B$ dan paket $C$, tidak mengetahui adanya program kursus komputer. Oleh karenanya, peserta kursus komputer hanya dari warga belajar saja yang diambilkan dari peserta program kesetaraan, tidak adanya peserta kursus dari luar. Jumlah tutor kursus komputer yang hanya berjumlah satu orang sekaligus membuat kelas kurang kondusif. Jika peserta kursus banyak yang bertanya, tentunya tutor akan menjadi semakin repot karena harus didampingi praktik secara intens. Demikian pula tutor bukan dari lulusan sarjana komputer ataupun ilmu teknologi informatika. Kondisi demikian seperti yang disampaikan oleh Laksana et al. (2017), bahwa faktor penghambat pelatihan terdapat pada peserta, kurangnya tenaga pengajar, waktu pelatihan yang diberikan terlalu singkat, dan terbatasnya sarana prasarana.

\section{SIMPULAN}

Upaya yang dilakukan tutor dalam meningkatkan keterampilan life skills warga belajar melalui kursus komputer sudah sangat baik. Terlihat upaya tutor dalam memberikan bekal pengetahuan yang berupa teori-teori komputer hingga didapatkannya kemampuan peserta kursus yang mencakup learning to know, learning to do, learning to be, dan learning to live together. Hasil program kursus komputer menjadikan peserta memiliki kemampuan mengaplikasikan dan mempraktikkan dengan benar penggunaan program Ms. Word, Ms. Excel, dan Ms. Power Point, serta membantu peserta kursus dengan mudah mendapat pekerjaan dan usaha. Faktor pendukung mencakup tingginya tingkat kemauan warga belajar untuk mengikuti kursus komputer, media pembelajaran yang cukup baik, metode pembelajaran yang baik, serta bantuan dana dari APBD yang cukup membantu. Sedangkan faktor penghambat kurangnya perekturan peserta kursus komputer, jumlah komputer yang lebih sedikit dibandingkan jumlah peserta kursus, terbatasnya subsidi pemerintah untuk mensubsidi peserta kursus, dan jumlah tutor yang hanya satu orang sekaligus bukan lulusan dari bidang komputer.

Diharapkan warga belajar yang telah mengikuti kursus komputer dapat memanfaatkan keterampilan yang dimilikinya untuk mendapatkan pekerjaan ataupun usaha, dan terus meningkatkan keterampilan komputernya. Kepada pihak pengelola diharapkan dapat terus menambah sarana dan prasarana khususnya dalam program kursus komputer, dan adanya penambahan jumlah tutor kursus komputer sekaligus keahliannya yang relevan dengan bidangnya serta kemampuan dalam mengajar. 


\section{DAFTAR PUSTAKA}

Anwar, A. (2006). Pendidikan kecakapan hidup. Bandung: Alfabeta.

Artasasmita, R. (1985). Pedoman kursus dan latihan. Bandung: Jurusan PLS FIP IKIP.

Depdiknas. (2002). Pendekatan kontekstual (teaching and learning. Jakarta: Direktorat Jenderal Pendidikan Dasar dan Menengah, Direktorat Pendidikan Lanjutan Pertama, Departemen Pendidikan Nasional.

Hamalik, H. (2003). Proses belajar mengajar. Jakarta: Bumi Aksara.

Herlinda, S., Hidayat, S., \& Djumena, I. (2017). Manajemen pelatihan hantaran dalam meningkatkan kecakapan hidup warga belajar di lembaga kursus dan pelatihan. Journal of Nonformal Education and
Community Empowerment, 1(1), 1-9.

Hidayat, D. (2017). Pengelolaan pembelajaran berbasis kewirausahaan masyarakat program kejar paket c, 3(1), 1-10.

Laksana, Y. S., Sholih, S., \& Naim, M. (2017). Pelatihan tata rias pengantin bagi wanita tuna susila dalam meningkatkan kemandirian usaha. Journal of Nonformal Education and Community Empowerment2, $1(1), 43-54$

Sudjana, D. (2003). Penilaian hasil proses belajar mengajar. Bandung: Remaja Rosdakarya.

Sudjana, D. (2004). Pendidikan nonformal: Wawasan, sejarah perkembangan, filsafat, teori pendukung, asas. Bandung: Falah Production. 